\title{
Effect of Integrated Nutrient Management on Soil Physico-Chemical Properties and Yield of Capsicum (Capsicum annuum)
}

\author{
Meera Devi*, Uday Sharma, Garima and Yourmila Kumari
}

Dr Y S Parmar University of Horticulture and Forestry, Nauni, Solan, Himachal Pradesh-173 230, India

*Corresponding author

\begin{tabular}{l} 
K e y w o r d s \\
$\begin{array}{l}\text { Capsicum annuum, } \\
\text { PGPR, Chemical } \\
\text { fertilizers, Growth, Fruit } \\
\text { yield and organic manure }\end{array}$ \\
\hline Article Info \\
\hline $\begin{array}{l}\text { Accepted: } \\
\text { 04 April } 2018 \\
\text { Available Online: } \\
\text { 10 May } 2018\end{array}$ \\
\hline
\end{tabular}

\section{Introduction}

With the indiscriminate use of fertilizers and chemicals there is increased risk of health hazards. Since vegetables are mostly consumed fresh or partially cooked they should be devoid of residues of chemical fertilizers. Besides, continuous use of chemical fertilizers has resulted in the depletion of soil health. For all these reasons, now much importance is being given to
Integrated Nutrient Management (INM). Bell pepper is an important agricultural crop, not only because of its economic importance, but also for the nutritional value of fruits, as is characterized by its high levels of vitamin $\mathrm{C}$ (ascorbic acid), pro-vitamin A (carotene) and calcium. Capsicum is consumed as salads, cooked, mixed, stuffed vegetable and is appreciated worldwide for its flavour, aroma and colour. It is also recommended for the treatment of dropsy, toothache and cholera 
(Peirce, 1987). With the increase in population, the demand for the crop has been increasing day by day. In India, in spite of its great potential the yield per unit area is very low than that of developed countries, mainly due to lack of proper production technologies especially, the nutrient management. For harnessing higher yield, balanced application of nutrition is a prerequisite. The continuous application of chemical fertilizers alone without use of organic manures has deteriorated soil health in terms of chemical, physical and biological characters resulting in decline in crop yield. On the other hand, organic manures such as farmyard manure and vermicompost are known to have beneficial effect on soil health but their limited nutrient content and their availability in large amount is a constraint for their wider usage. This indicates that sole application of organics or inorganic fertilizers are in no way a suitable solution for maintaining soil health and enhancing crop productivity. So the solution lies in the integrated use of chemical fertilizers and organic manures for obtaining sustainable crop production, better nutrient availability and efficient nutrient use, besides reducing nutrient losses (Hegde, 1997) and improving fruit quality (Singh 2004).

\section{Materials and Methods}

The field experiment was conducted in two consecutive years (2015 and 2016) in the Department of Soil Science and Water Management, Dr Y S Parmar University of Horticulture and Forestry, Nauni, Solan, Himachal Pradesh. Initial soil samples (0-15 $\mathrm{cm}$ depth) were collected to analyze the properties of soil before the experiment started (Table 2). At the time of termination of experiment soil status was again determined. Soil samples were analyzed for organic carbon, available nitrogen, available phosphorus, available potassium, exchangble calcium and magnesium and sulphate sulphur as per standard procedures (Table 1). A total of nine treatments; $\mathrm{T}_{1}$-Absolute control, $\mathrm{T}_{2}$ $70 \% \mathrm{NPKM}+30 \% \mathrm{~N}$ through FYM and VC (50:50), $\mathrm{T}_{3}-80 \% \mathrm{NPKM}+20 \% \mathrm{~N}$ through FYM and VC (50:50), $\mathrm{T}_{4}-90 \%$ NPKM $+10 \%$ $\mathrm{N}$ through FYM and VC (50:50), $\mathrm{T}_{5}-100 \%$ $\mathrm{NPK}+\mathrm{FYM}, \mathrm{T}_{6}-100 \%$ NPK + Vermicompost, $\mathrm{T}_{7}-110 \%$ NPKM (50:50 of FYM and VC as per $\mathrm{N}$ content), $\mathrm{T}_{8}-120 \%$ NPKM (50:50 of FYM and VC as per $\mathrm{N}$ content), $\mathrm{T}_{9}-130 \%$ NPKM (50:50 of FYM and $\mathrm{VC}$ as per $\mathrm{N}$ content) were evaluated in Randomized Block Design with the three replications. Manures were incorporated as basal dose at the time of field preparation. Half dose of $\mathrm{N}$ and full amount of $\mathrm{P}$ and $\mathrm{K}$ were applied as basal during planting, and rest of $\mathrm{N}$ was top dressed in two splits at 30 and 60 days after planting. The source of nitrogen, phosphorus and potash were urea, single super phosphate and muriate of potash, respectively. PGPR was applied as root dip treatment for 30 minutes before transplanting of capsicum. The observations were recorded on different quantitative characters of capsicum, viz. (plant height, number of fruits per plant, fruit weight, fruit size, ascorbic acid content and fruit yield). Five plant samples at the time of harvest were also randomly collected from each plot and mixed separately to determine concentrations of $\mathrm{N}, \mathrm{P}$ and $\mathrm{K}$ content in fruits at harvest using standard procedures (Table 1).

\section{Results and Discussion}

Integrated nutrient management showed significant impact on yield and growth attributes of capsicum. Treatment $\mathrm{T}_{2}$ exerted significant influence on growth parameters like plant height $(\mathrm{cm})$, number of fruits per plant, fruit weight $(\mathrm{g})$, fruit size $\left(\mathrm{cm}^{2}\right)$, ascorbic acid content (mg $100 \mathrm{~g}^{-1}$ ), and fruit yield $\left(\mathrm{q} \mathrm{ha} \mathrm{ha}^{-1}\right)$ during both the years of investigation. Plant height in capsicum was significantly affected by the treatments in the experiment. Maximum plant height $(65.00 \mathrm{~cm}$, 
$64.03 \mathrm{~cm})$ were found with treatment $\mathrm{T}_{3}(80 \%$ NPKM $+20 \% \mathrm{~N}$ through FYM and VC $(50: 50)$ and minimum $(53.40 \mathrm{~cm}, 51.80 \mathrm{~cm})$ under $\mathrm{T}_{1}$ (control) in the year 2015 and 2016, respectively (Table 3 ). Pooled data revealed that significantly higher plant height was recorded under $\mathrm{T}_{3}(64.70 \mathrm{~cm})$ which was statistically at par with $\mathrm{T}_{8}(64.20 \mathrm{~cm})$ and $\mathrm{T}_{9}$ $(63.50 \mathrm{~cm})$ and lowest under $T_{1}(52.60 \mathrm{~cm})$. The possible reason for maximum values in this treatment might be due to decomposition of organic matter with the subsequent release of available nutrients for the plants for growth. Vermicompost and PGPR applied with inorganic fertilizer improve the effectiveness of chemical fertilizers. Application of PGPR helps in improving number of biological activities of desired microorganisms in soil and improves growth of capsicum. Number of fruits per plants also influenced significantly with the treatments under investigation (Table 2). Highest number of fruits per plant were recorded in treatment $T_{3}(15.50,16.00)$ and lowest under treatment $\mathrm{T}_{1}(10.90,10.40)$ during 2015 and 2016, respectively. The pooled data also showed highest number of fruits i.e., 15.80 in $\mathrm{T}_{3}(80 \% \mathrm{NPKM}+20 \% \mathrm{~N}$ through FYM and VC (50:50). This treatment was statistically at par with $T_{7}, T_{8}$ and $T_{9}$. The lowest number of fruits per plant (10.60) was recorded in $T_{1}$ (control). More number of fruits also may be due to better inorganic nitrogen utilization in the presence of biofertilizers, enhanced biological nitrogen fixation and better development of root system and possible higher synthesis of plant growth hormones resulting in to more number of fruits per plants and hence more yield. Similar views have also been expressed by Jaipaul $e t$ al., 2011. Higher ascorbic acid content $(152.14 \mathrm{mg} / 100 \mathrm{~g})$ was also recorded in treatment $\mathrm{T}_{3}$ (Table 2) which was statistically at par with $\mathrm{T}_{9}(151.55 \mathrm{mg} / 100 \mathrm{~g})$ and $\mathrm{T}_{8}$ $(150.68 \mathrm{mg} / 100 \mathrm{~g})$ and lowest under $\mathrm{T}_{1}$ $(128.25 \mathrm{mg} / 100 \mathrm{~g})$. The possible reason for increase in ascorbic acid content may be due to the reason that vitamin $\mathrm{C}$ is synthesized from carbohydrate. These findings are in close agreement with those reported earlier by Singh (2004).

In the year 2015, the maximum fruit size $\left(36.30 \mathrm{~cm}^{2}\right)$ was recorded in treatment $\mathrm{T}_{3}(80$ $\%$ NPKM $+20 \% \mathrm{~N}$ through FYM and VC (50:50) and minimum fruit size $\left(26.70 \mathrm{~cm}^{2}\right)$ was in $\mathrm{T}_{1}$ (Table 3). However, in year 2016, the maximum fruit size $\left(37.10 \mathrm{~cm}^{2}\right)$ was recorded in treatment $T_{3}$ and minimum fruit size $\left(25.00 \mathrm{~cm}^{2}\right)$ was in $T_{1}$. The pooled data for both the years of the investigation revealed that maximum fruit size $\left(36.70 \mathrm{~cm}^{2}\right)$ was in $\mathrm{T}_{3}$ and minimum fruit size $\left(25.80 \mathrm{~cm}^{2}\right)$ under Treatment $T_{1}$. Increased fruit size due to integrated use of organic and inorganic fertilizers with PGPR may be attributed to the better root proliferation, uptake of nutrients and water, higher leaf area, more photosynthesis and enhanced food accumulation, increasing availability of atmospheric nitrogen and soil phosphorus by microbial inoculants might have played a vital role in better plant growth and increased fruit size. Different treatments resulted significant variation with respect of fruit weight during both the years of the studies (Table 4). Maximum individual fruit weight $(65.90 \mathrm{~g})$ was recorded in $T_{3}$ and significantly higher than all the treatments in the first year of study and minimum $(52.00 \mathrm{~g})$ under $\mathrm{T}_{1}$. Similar trend was also noticed in the second year where it was maximum $(66.30 \mathrm{~g})$ in the same treatment i.e., $\mathrm{T}_{3}$ and minimum $(50.30 \mathrm{~g})$ under $\mathrm{T}_{1}$. The pooled analysis of the data recorded maximum fruit weight $(66.10 \mathrm{~g})$ in $\mathrm{T}_{3}$ and minimum $(51.20 \mathrm{~g})$ under $\mathrm{T}_{1}$. The treatment that received $80 \% \mathrm{NPKM}+20 \% \mathrm{~N}$ through FYM and VC (50:50) observed better fruit yield irrespective of integration with organics (FYM and VC) or bacterium inoculation during both the years of study (Table 3). During 2015, significantly higher yield $\left(343.30 \mathrm{q} \mathrm{ha}^{-1}\right)$ was recorded in $\mathrm{T}_{3}$. Similar trend was also recorded during 
second year (2016), $\mathrm{T}_{3}$ recorded significantly higher fruit yield $\left(346.30 \mathrm{q} \mathrm{ha}^{-1}\right)$. However, lower yield was recorded under $\mathrm{T}_{1}$ (213.30, 204.30) in both the years, respectively. Pooled data revealed that significantly higher yield was recorded under $\mathrm{T}_{3}\left(344.80 \mathrm{q} \mathrm{ha}^{-1}\right)$ and lower under $\mathrm{T}_{1}\left(208.80 \mathrm{q} \mathrm{ha}^{-1}\right)$. The findings suggested that, reduction of $20 \%$ recommended inorganic is possible if FYM and Vermicompost with PGPR inoculation of plants. Kanwar and Paliyal (2006) were able to execute a net saving of $50 \%$ of synthetic fertilizer by substituting Vermicompost for FYM along with $100 \%$ NPK.

Highest $\mathrm{N}$ contents were observed under $\mathrm{T}_{3}$ i.e. 4.33 and 4.39 per cent, respectively during 2015 and 2016, respectively. Likewise, pooled analysis of data also showed that the effect of different treatments was significant and the pattern was almost similar to both the years of study. Highest $\mathrm{N}$ contents of 4.36 per cent was observed under $\mathrm{T}_{3}$ treatment which were found statistically at par with $\mathrm{T}_{9}(4.28 \%)$ and $\mathrm{T}_{8}$ (4.31\%).

Phosphorus content was also significant during both the years of study. However, higher $\mathrm{P}$ contents were observed under $\mathrm{T}_{3}$ $(0.59 \%$ and $0.62 \%)$ and minimum under $\mathrm{T}_{1}$ $(0.32 \%$ and $0.28 \%)$, respectively during 2015 and 2016. Higher $\mathrm{K}$ was recorded under $\mathrm{T}_{3}$ (3.31\%) and lower with $\mathrm{T}_{1}(2.18 \%)$ However, in the second year of study, higher $\mathrm{K}$ was again observed under $\mathrm{T}_{3}$ treatment $(3.33 \%)$ and lower under $\mathrm{T}_{1}(2.09 \%)$. Pooled analysis of data also showed that the effect of different nutrient sources was significant and higher $\mathrm{K}$ was also recorded under $\mathrm{T}_{3}(3.32 \%)$ and lower with $\mathrm{T}_{1}(2.14 \%)$.

The higher content of macro-nutrients (NPK) in leaves due to the differential behavior of nutrient distribution among different parts of capsicum in the present study may be explained in terms of their retranslocation. In the literature, N, P and $\mathrm{K}$ are generally regarded as being retranslocated. Chander $e t$ al., (2010) reported an increase in nutrient content as a result of FYM. This may be due to the beneficial effect of FYM on nutrient availability in soil and improvement in soil physical and microbiological properties.

The higher macro and micro nutrient element content observed under integrated applications may be due to the fact that organic manures, besides being rich source, mobilized the micronutrient content of soil. They attributed such effects to the increased root activity and formation of micronutrient chelates, thereby, increasing their uptake.

Table.1 Methods followed for the analysis of soil and plant parameters

\begin{tabular}{l|l|l|}
$\begin{array}{l}\text { Sr. No. } \\
\text { 1. }\end{array}$ & \multicolumn{1}{|c|}{ Parameter } & \multicolumn{1}{c}{ Reference (Method) } \\
\hline 2. & Available $\mathrm{N}$ & Alkaline potassium permanganate method (Subbiah and Asija, 1956) \\
\hline 3. & Available $\mathrm{P}$ & Olsen's method (Olsen et al., 1954) \\
\hline 4. & Available K & Ammonium acetate method (Merwin and Peech, 1951) \\
\hline 5. & Exchangeable Ca & Ammonium acetate method (Merwin and Peech, 1951) \\
\hline 6. & $\mathrm{SO}_{4}{ }^{2-}-\mathrm{S}$ & $0.15 \% \mathrm{CaCl}_{2}$ extractant and turbidimetric determination (Chesnin and Yien, 1950) \\
\hline Leaf analysis & $\mathrm{N}$ & Microkjeldhal method (Jackson, 1973) \\
\hline 1. & $\mathrm{P}$ & Vando-molybdate phosphoric yellow color method (Jackson, 1973) \\
\hline 2. & $\mathrm{K}$ & Flame photometer method (Jackson, 1973) \\
\hline 3. & &
\end{tabular}


Table.2 Physico-chemical properties of experimental soil before the start of experiment

\begin{tabular}{|l|c|}
\hline \multicolumn{1}{|c|}{ Properties } & Value \\
\hline Organic carbon $\left(\mathrm{g} \mathrm{kg}^{-1}\right)$ & 10.98 \\
\hline Available $\mathrm{N}\left(\mathrm{kg} \mathrm{ha}^{-1}\right)$ & 351.78 \\
\hline Available P $\left(\mathrm{kg} \mathrm{ha}^{-1}\right)$ & 56.89 \\
\hline Available K $\left(\mathrm{kg} \mathrm{ha}^{-1}\right)$ & 257.69 \\
\hline Exchangeable Ca $\left.\left(\mathrm{cmol}^{-1} \mathrm{p}^{+}\right) \mathrm{kg}^{-1}\right)$ & 3.18 \\
\hline Sulphate Sulphur $\left(\mathrm{kg} \mathrm{ha}^{-1}\right)$ & 43.87 \\
\hline
\end{tabular}

Table.3 Effect of Integrated nutrient management on plant height, number of fruits per plant, total chlorophyll content and ascorbic acid of capsicum

\begin{tabular}{|c|c|c|c|c|c|c|c|c|c|}
\hline \multirow{2}{*}{$\begin{array}{c}\text { Treatment } \\
\text { s }\end{array}$} & \multicolumn{3}{|c|}{ Plant height (cm) } & \multicolumn{3}{|c|}{ No. of fruits per plant } & \multicolumn{3}{|c|}{ Ascorbic acid (mg $\left.100 \mathrm{~g}^{-1}\right)$} \\
\hline & 2014-15 & 2015-16 & Pooled & 2014-15 & 2015-16 & Pooled & 2014-15 & 2015-16 & Pooled \\
\hline$T_{1}$ & 53.4 & 51.8 & 52.6 & 10.9 & 10.4 & 10.6 & 128.22 & 128.29 & 128.25 \\
\hline $\mathbf{T}_{2}$ & 59.3 & 59.8 & 59.5 & 13.1 & 13.7 & 13.4 & 143.15 & 144.66 & 143.90 \\
\hline $\mathbf{T}_{3}$ & 65.0 & 64.3 & 64.7 & 15.5 & 16.0 & 15.8 & 151.36 & 152.93 & 152.14 \\
\hline $\mathbf{T}_{4}$ & 59.7 & 60.0 & 59.9 & 14.0 & 14.3 & 14.1 & 146.89 & 145.26 & 146.08 \\
\hline$T_{5}$ & 58.2 & 58.6 & 58.4 & 11.5 & 12.3 & 11.9 & 135.74 & 135.88 & 135.81 \\
\hline $\mathrm{T}_{6}$ & 58.6 & 58.8 & 58.7 & 12.9 & 13.4 & 13.1 & 141.99 & 139.16 & 140.58 \\
\hline $\mathbf{T}_{7}$ & 62.1 & 62.4 & 62.2 & 15.0 & 15.9 & 15.5 & 147.36 & 148.58 & 147.97 \\
\hline$T_{8}$ & 63.2 & 65.2 & 64.2 & 15.1 & 15.8 & 15.4 & 151.36 & 150.00 & 150.68 \\
\hline $\mathrm{T}_{9}$ & 63.1 & 63.8 & 63.5 & 15.3 & 15.7 & 15.5 & 150.81 & 152.29 & 151.55 \\
\hline Mean & 60.3 & 60.5 & & 13.70 & 14.20 & & 143.65 & 144.56 & \\
\hline $\mathrm{CD}_{(0.05)}$ & 2.96 & 2.02 & & 1.07 & 1.44 & & 6.40 & 6.23 & \\
\hline $\mathbf{T}$ & & 1.72 & & & 0.86 & & & 4.28 & \\
\hline $\mathbf{Y}$ & & NS & & & 0.41 & & & NS & \\
\hline$T \times Y$ & & NS & & & NS & & & NS & \\
\hline
\end{tabular}

Table.4 Effect of Integrated nutrient management on fruit size, fruit weight and yield of capsicum

\begin{tabular}{|c|c|c|c|c|c|c|c|c|c|}
\hline Treatments & \multicolumn{3}{|c|}{ Fruit size $\left(\mathrm{cm}^{2}\right)$} & \multicolumn{3}{|c|}{ Fruit weight (g) } & \multicolumn{3}{|c|}{ Yield $\left(\mathrm{q} \mathrm{ha}^{-1}\right)$} \\
\hline & 2014-15 & 2015-16 & Pooled & 2014-15 & 2015-16 & Pooled & 2014-15 & 2015-16 & Pooled \\
\hline $\mathrm{T}_{1}$ & 26.7 & 25.0 & 25.8 & 52.0 & 50.3 & 51.2 & 213.3 & 204.3 & 208.8 \\
\hline $\mathbf{T}_{2}$ & 33.2 & 33.7 & 33.5 & 62.1 & 62.6 & 62.4 & 303.3 & 303.7 & 303.5 \\
\hline $\mathrm{T}_{3}$ & 36.3 & 37.1 & 36.7 & 65.9 & 66.3 & 66.1 & 343.3 & 346.3 & 344.8 \\
\hline$T_{4}$ & 33.1 & 34.0 & 33.5 & 61.7 & 62.0 & 61.9 & 329.5 & 330.0 & 329.8 \\
\hline$T_{5}$ & 30.4 & 31.0 & 30.7 & 58.1 & 58.4 & 58.3 & 266.3 & 271.4 & 268.8 \\
\hline $\mathrm{T}_{6}$ & 32.2 & 32.6 & 32.4 & 60.5 & 60.8 & 60.7 & 281.1 & 283.3 & 282.2 \\
\hline $\mathbf{T}_{7}$ & 34.9 & 36.4 & 35.6 & 64.6 & 64.7 & 64.6 & 340.5 & 341.9 & 341.2 \\
\hline $\mathbf{T}_{8}$ & 35.7 & 36.0 & 35.9 & 64.3 & 64.7 & 64.5 & 341.2 & 342.6 & 341.9 \\
\hline$T_{9}$ & 35.1 & 36.5 & 35.8 & 64.1 & 64.4 & 64.2 & 341.3 & 342.9 & 342.1 \\
\hline Mean & 33.10 & 33.60 & & 61.50 & 61.60 & & 307.0 & 307.0 & \\
\hline $\mathrm{CD}_{(0.05)}$ & 1.16 & 2.80 & & 4.38 & 5.19 & & 7.56 & 9.35 & \\
\hline $\mathbf{T}$ & 1.45 & & & 3.26 & & & 5.76 & & \\
\hline $\bar{Y}$ & NS & & & NS & & & NS & & \\
\hline$T \times Y$ & NS & & & NS & & & NS & & \\
\hline
\end{tabular}


Int.J.Curr.Microbiol.App.Sci (2018) 7(5): 363-372

Table.5 Effect of Integrated nutrient management on leaf nitrogen, phosphorus and potassium content of capsicum

\begin{tabular}{|c|c|c|c|c|c|c|c|c|c|}
\hline Treatments & \multicolumn{3}{|c|}{$\mathbf{N}(\%)$} & \multicolumn{3}{|c|}{$\mathbf{P}(\%)$} & \multicolumn{3}{|c|}{$\mathbf{K}(\%)$} \\
\hline & $\begin{array}{c}\text { 2014- } \\
15\end{array}$ & $\begin{array}{c}2015- \\
16\end{array}$ & Pooled & $\begin{array}{c}2014- \\
15\end{array}$ & $\begin{array}{c}2015 \\
16\end{array}$ & Pooled & $\begin{array}{c}2014- \\
15\end{array}$ & $\begin{array}{c}2015- \\
16\end{array}$ & Pooled \\
\hline $\mathbf{T}_{1}$ & 3.93 & 3.82 & 3.88 & 0.36 & 0.31 & 0.33 & 2.22 & 2.14 & 2.18 \\
\hline $\mathbf{T}_{2}$ & 4.89 & 5.03 & 4.96 & 0.62 & 0.65 & 0.63 & 2.99 & 3.06 & 3.02 \\
\hline $\mathbf{T}_{3}$ & 5.18 & 5.24 & 5.21 & 0.79 & 0.82 & 0.80 & 3.19 & 3.22 & 3.21 \\
\hline $\mathbf{T}_{4}$ & 5.03 & 5.10 & 5.07 & 0.62 & 0.65 & 0.64 & 3.01 & 3.11 & 3.06 \\
\hline $\mathbf{T}_{5}$ & 4.56 & 4.52 & 4.54 & 0.54 & 0.51 & 0.52 & 2.81 & 2.91 & 2.86 \\
\hline$T_{6}$ & 4.64 & 4.66 & 4.65 & 0.57 & 0.60 & 0.59 & 2.92 & 2.95 & 2.93 \\
\hline $\mathbf{T}_{7}$ & 4.93 & 5.08 & 5.01 & 0.65 & 0.63 & 0.64 & 3.10 & 3.16 & 3.13 \\
\hline$T_{8}$ & 5.10 & 5.15 & 5.12 & 0.71 & 0.74 & 0.73 & 3.11 & 3.09 & 3.11 \\
\hline $\mathbf{T}_{9}$ & 5.15 & 5.20 & 5.18 & 0.73 & 0.79 & 0.76 & 3.15 & 3.15 & 3.15 \\
\hline Mean & 4.82 & 4.87 & & 0.62 & 0.63 & & 2.94 & 2.98 & \\
\hline $\mathrm{CD}_{(0.05)}$ & 0.60 & 0.60 & & 0.14 & 0.14 & & 0.10 & 0.17 & \\
\hline $\mathbf{T}$ & & 0.41 & & & 0.10 & & & 0.10 & \\
\hline $\mathbf{Y}$ & & NS & & & NS & & & NS & \\
\hline $\mathbf{T} \times \mathbf{Y}$ & & NS & & & NS & & & NS & \\
\hline
\end{tabular}

Table.6 Effect of Integrated nutrient management on organic carbon, available nitrogen, phosphorus and potassium of capsicum

\begin{tabular}{|c|c|c|c|c|c|c|c|c|c|c|c|c|}
\hline Treatm & \multicolumn{3}{|c|}{$\mathrm{OC}\left(\mathrm{g} \mathrm{kg}^{-1}\right)$} & \multicolumn{3}{|c|}{ Available $\mathbf{N}\left(\mathrm{kg} \mathrm{ha}^{-1)}\right.$} & \multicolumn{3}{|c|}{ A vailable P $\left(\mathrm{kg} \mathrm{ha}^{-1)}\right.$} & \multicolumn{3}{|c|}{ Available K (kg ha $\left.{ }^{-1}\right)$} \\
\hline & $\begin{array}{c}\text { 2014- } \\
15\end{array}$ & $\begin{array}{c}2015- \\
16\end{array}$ & $\begin{array}{c}\text { Pool } \\
\text { ed }\end{array}$ & $\begin{array}{c}\text { 2014- } \\
15\end{array}$ & $\begin{array}{c}2015- \\
16\end{array}$ & $\begin{array}{c}\text { Poole } \\
\text { d }\end{array}$ & $\begin{array}{c}2014- \\
15\end{array}$ & $\begin{array}{c}2015- \\
16\end{array}$ & $\begin{array}{c}\text { Pool } \\
\text { ed }\end{array}$ & $\begin{array}{c}\text { 2014- } \\
15\end{array}$ & $\begin{array}{c}2015- \\
16\end{array}$ & Pooled \\
\hline$T_{1}$ & 10.40 & 10.22 & 10.31 & 306.88 & 301.51 & 304.20 & 48.17 & 44.61 & 46.39 & 226.14 & 218.91 & 222.53 \\
\hline $\mathbf{T}_{2}$ & 12.37 & 12.66 & 12.51 & 379.37 & 382.84 & 381.11 & 64.76 & 65.78 & 65.27 & 278.50 & 282.81 & 280.65 \\
\hline $\mathbf{T}_{3}$ & 12.42 & 12.73 & 12.58 & 397.29 & 399.03 & 398.16 & 68.32 & 69.66 & 68.99 & 282.00 & 284.33 & 283.17 \\
\hline $\mathbf{T}_{4}$ & 12.25 & 12.42 & 12.34 & 386.93 & 387.13 & 387.03 & 65.69 & 66.02 & 65.86 & 279.71 & 283.44 & 281.58 \\
\hline $\mathbf{T}_{5}$ & 11.40 & 11.66 & 11.53 & 366.96 & 368.26 & 367.61 & 61.47 & 62.25 & 61.86 & 271.59 & 274.99 & 273.29 \\
\hline$T_{6}$ & 12.03 & 12.40 & 12.22 & 371.63 & 374.84 & 373.24 & 62.15 & 63.07 & 62.61 & 274.36 & 277.50 & 275.93 \\
\hline$T_{7}$ & 12.48 & 12.79 & 12.64 & 405.81 & 407.80 & 406.80 & 67.03 & 68.50 & 67.77 & 284.84 & 291.69 & 288.27 \\
\hline$T_{8}$ & 12.54 & 12.95 & 12.75 & 406.52 & 409.35 & 407.94 & 68.29 & 69.88 & 69.09 & 285.07 & 292.26 & 288.66 \\
\hline$T_{9}$ & 12.61 & 13.07 & 12.84 & 408.73 & 411.02 & 409.88 & 68.85 & 71.40 & 70.13 & 289.36 & 297.58 & 293.47 \\
\hline Mean & 12.06 & 12.32 & & 381.12 & 382.42 & & 63.86 & 64.58 & & 274.62 & 278.17 & \\
\hline $\mathrm{CD}_{(0.05)}$ & 0.54 & 0.51 & & 4.69 & 4.45 & & 2.28 & 2.71 & & 6.32 & 7.21 & \\
\hline $\mathbf{T}$ & & 0.35 & & & 3.10 & & & 1.70 & & & 4.60 & \\
\hline $\mathbf{Y}$ & & 0.17 & & & NS & & & NS & & & 2.17 & \\
\hline $\mathrm{T} \times \mathrm{Y}$ & & NS & & & NS & & & NS & & & NS & \\
\hline
\end{tabular}


Table.7 Effect of Integrated nutrient management on exchangeable calcium, magnesium and sulphate sulphur of capsicum

\begin{tabular}{|c|c|c|c|c|c|c|}
\hline Treatments & \multicolumn{3}{|c|}{ Exchangeable Ca (meq/100g) } & \multicolumn{3}{|c|}{$\mathrm{SO}_{4}{ }^{2-} \mathrm{S}\left(\mathrm{kg} \mathrm{ha}^{-1}\right)$} \\
\hline & 2014-15 & 2015-16 & Pooled & 2014-15 & 2015-16 & Pooled \\
\hline $\mathbf{T}_{1}$ & 2.61 & 2.52 & 2.57 & 36.88 & 33.99 & 35.44 \\
\hline $\mathbf{T}_{2}$ & 3.54 & 3.58 & 3.56 & 50.14 & 51.66 & 50.90 \\
\hline $\mathbf{T}_{3}$ & 3.60 & 3.66 & 3.63 & 53.43 & 54.94 & 54.19 \\
\hline $\mathbf{T}_{4}$ & 3.56 & 3.60 & 3.58 & 51.18 & 51.79 & 51.49 \\
\hline $\mathbf{T}_{5}$ & 3.50 & 3.53 & 3.52 & 45.32 & 46.05 & 45.69 \\
\hline$T_{6}$ & 3.52 & 3.55 & 3.53 & 47.95 & 48.68 & 48.32 \\
\hline $\mathbf{T}_{7}$ & 3.77 & 4.02 & 3.90 & 56.58 & 57.48 & 57.03 \\
\hline $\mathbf{T}_{8}$ & 3.87 & 4.03 & 3.95 & 57.14 & 58.61 & 57.88 \\
\hline $\mathrm{T}_{9}$ & 4.09 & 4.18 & 4.13 & 60.41 & 61.02 & 60.71 \\
\hline Mean & 3.56 & 3.63 & & 51.00 & 51.58 & \\
\hline $\mathrm{CD}_{(0.05)}$ & 0.36 & 0.39 & & 2.00 & 1.93 & \\
\hline $\mathbf{T}$ & & 0.26 & & & 1.33 & \\
\hline $\mathbf{Y}$ & & NS & & & NS & \\
\hline $\mathrm{T} \times \mathrm{Y}$ & & NS & & & NS & \\
\hline
\end{tabular}

\section{Soil properties}

Integrated nutrient management influenced the soil properties over a period of two years. Addition of organic, inorganic, chemical and biofertilizers (PGPR) in different combinations had a positive effect on organic carbon, available nitrogen, phosphorus, potassium, exchangeable calcium, magnesium and sulphate sulphur.

On the basis of pooled data (Table 6), it is evident that increase of organic carbon content was more pronounced in $130 \%$ NPKM (50:50 of FYM and VC as per N content) with PGPR $\left(\mathrm{T}_{9}\right)$ recorded significantly higher organic carbon $(12.84 \mathrm{~g}$ $\mathrm{kg}^{-1}$ ) was higher under treatment $\mathrm{T}_{9}$ which was statistically at par with $\mathrm{T}_{8}\left(12.75 \mathrm{~g} \mathrm{~kg}^{-1}\right)$ and $\mathrm{T}_{3}\left(12.58 \mathrm{~g} \mathrm{~kg}^{-1}\right)$ and lowest $\left(10.31 \mathrm{~g} \mathrm{~kg}^{-1}\right)$ under $\mathrm{T}_{1}$. Organic carbon in soil increased significantly with the increase level of fertilizers along with FYM and Vermicompost. Choudhary et al., (2005) reported that the incorporation of biofertilizers and FYM with inorganic fertilizers significantly improved the organic carbon content of the soil in tomato.

Pooled analysis of data revealed that significantly higher available $\mathrm{N}$ (Table 5) was recorded under $\mathrm{T}_{9}\left(409.88 \mathrm{~kg} \mathrm{ha}^{-1}\right)$ which was statistically at par with $\mathrm{T}_{8}\left(407.94 \mathrm{~kg} \mathrm{ha}^{-1}\right)$ and lowest under $\mathrm{T}_{1} \quad\left(304.20 \mathrm{~kg} \mathrm{ha}^{-1}\right)$. The increased available $\mathrm{N}$ due to incorporation of organic material is attributed to the enhanced mineralization. Swain et al., (2013) also noted maximum available nitrogen in the plots supplied with $100 \%$ chemical fertilizers and explained that in chemical fertilizers, mineralization process was faster and thereby has shown immediate release of $\mathrm{N}$ and its availability in the soil. Similar trend was observed for available phosphorous content in soil (Table 6). Significantly higher available phosphorus (68.85 $\mathrm{kg} \mathrm{ha}^{-1}, 71.40 \mathrm{~kg} \mathrm{ha}^{-1}$ ) content also under $\mathrm{T}_{9}$ and lower was noticed under $\mathrm{T}_{1}$ (48.17 and $44.61 \mathrm{~kg} \mathrm{ha}^{-1}$ ) during 2015-2016, respectively. Pooled analysis showed that the effect of different treatments 
was significant and trend was similar to both the years of study. Significantly higher phosphorus was recorded in $\mathrm{T}_{9}(70.13 \mathrm{~kg}$ $\mathrm{ha}^{-1}$ ), which was statistically at par with $\mathrm{T}_{8}$ (69.09 kg ha $\mathrm{kg}^{-1}$ ) and $\mathrm{T}_{3}\left(68.99 \mathrm{~kg} \mathrm{ha}^{-1}\right)$, whereas lowest under $\mathrm{T}_{1}$ i.e. $46.39 \mathrm{~kg} \mathrm{ha}^{-1}$. Addition of organic manure like FYM, crop residue along with inorganic fertilizer had a beneficial effect in increasing the phosphate availability, which was also observed by Upadhyay et al., (2012). The increase in available $\mathrm{P}$ might have resulted by the solubilization of insoluble $\mathrm{P}$ due to application of PGPR isolates having very high $P$ solubilization efficiency. Pooled analysis of data revealed that the effect of different treatments was significant and higher potassium $293.47 \mathrm{~kg} \mathrm{ha}^{-1}$ was recorded under $\mathrm{T}_{9}$ and lowest $222.53 \mathrm{~kg} \mathrm{ha}^{-1}$ in $\mathrm{T}_{1}$ (Table 6). The beneficial effect of Vermicompost and FYM on available $\mathrm{K}$ may be ascribed to the direct potassium addition to the potassium pool of the soil besides the reduction in potassium fixation and its release due to interaction of organic matter with clay particles. The beneficial effect of integration of organic manures + bio-inoculants + chemical fertilizers in promoting inherent fertility status of soil was earlier reported by Parmar et al., (2006).

Pooled analysis of data (Table 7) revealed that significantly higher exchangeable calcium was recorded under $\mathrm{T}_{9}\left(4.13 \mathrm{cmol}\left(\mathrm{p}^{+}\right) \mathrm{kg}^{-1}\right)$ which was found statistically at par with $\mathrm{T}_{8}$ $\left(3.95 \mathrm{cmol}\left(\mathrm{p}^{+}\right) \mathrm{kg}^{-1}\right)$ and lower under $\mathrm{T}_{1}(2.57$ cmol $\left.\left(\mathrm{p}^{+}\right) \mathrm{kg}^{-1}\right)$. Exchangeable $\mathrm{Ca}$ was significantly influenced by organic sources of nutrients with or without inoculation. Since Phosphorus is synergistic to calcium and this might be the reason for more uptake of calcium with increasing phosphorus concentrations. Significantly higher amount of exchangeable $\mathrm{Ca}$ might be due to the production of nutrient solubilizing enzymes by microorganisms (Kholer et al., 2007).
Organic and inorganic sources of nutrients along with PGPR had significant effect on sulphate sulphur content during both the years of study (Table 7). For the year 2015, significantly higher sulphate sulphur was recorded under $\mathrm{T}_{9}\left(60.41 \mathrm{~kg} \mathrm{ha}^{-1}\right)$ and lower with $\mathrm{T}_{1}\left(36.88 \mathrm{~kg} \mathrm{ha}^{-1}\right)$. Almost similar trend was recorded during second year, highest sulphate sulphur was observed under $\mathrm{T}_{9}$ $\left(61.02 \mathrm{~kg} \mathrm{ha}^{-1}\right)$ and lowest was in $\mathrm{T}_{1}(33.99 \mathrm{~kg}$ $\left.\mathrm{ha}^{-1}\right)$. The application of FYM or in combination with Vermicompost generally resulted in buildup of available $S$ status of the soil. Singh and Singh (1977) in an incubation study observed an increase in the soil microorganism population apparently utilize organically bound $\mathrm{S}$ and convert it into cystine and methionine, which are further converted in to inorganic sulphate by microorganisms. The buildup of available $S$ in soil with the addition of FYM after the harvest of crop has also been reported by Nambiar and Ghosh (1984).

On the basis of two years study, it may be concluded that the treatment $\mathrm{T}_{9} \quad(130 \%$ NPKM + PGPR) registered significantly maximum values of organic carbon, macro (N, P, K, Exchangeable $\mathrm{Ca}$ and $\mathrm{SO}_{4}{ }^{2-} \mathrm{S}$ ). The results on plant nutrient content and growth parameters recorded maximum under treatment $\mathrm{T}_{3}$ ). Increase in fruit yield over $\mathrm{T}_{5}$ (RPF) with higher quality. Hence, PGPR with 80 per cent of recommended dose of $\mathrm{N}, \mathrm{P}$ and $\mathrm{K}$ fertilizers along with FYM and VC suggested as a cost effective nutrient module for getting higher yield and quality with $20 \%$ net saving of fertilizers in capsicum on sustainable basis.

\section{References}

Chander, G, Verma, T. S. and Sharma, S. (2010). Nutrient content of cauliflower Brassica oleracea L. var. botrytis) as influenced by boron and farm yard 
manure in North West Himalayan alfisols. Journal of the Indian Society of Soil Science. 58(2), 248-251.

Chaudhary, R. S. Das, A.and Patnaik, U. S. (2005). Organic farming for vegetable production using vermicompost and FYM in Kokriguda watershed of Orissa. Indian Journal of Soil Conservation. 31(2), 203-206.

Chesnin, L. and Yien, C. H. (1950). Turbidimetric determination of available sulphates. Soil Science Society of America Proceedings. 15, 149-151.

Hegde, D.M. (1997). Nutrient requirement of solanaceous vegetable crops. Extension Bulletin- ASPAC Food and Fertilizer Technology Centre 44.

Jackson, M. L. (1973). Soil chemical analysis. Prentice Hall, New Delhi. 111-126.

Jaipaul, S. Kumar, A. and Sharma, A.K. (2011). Growth and yield of capsicum (Capsicum annum) and garden pea (Pisum sativum) as influenced by organic manures and biofertilizers. Indian Journal of Agricultural Sciences. 81 (7), 637-642.

Kanwar, K. and Paliyal, S. S. (2006). Effect of integrated nutrient management on growth and yield of cabbage. Himachal Journal of Agricultural Research. 31(1), 15-20.

Kholer, J. Caravaca, F. Carrasco, L. and Roldan, A. (2007). Interactions between a plant growth promoting rhizobacterium, an AM fungus and a phosphate solubilising fungus in the rhizosphere of Lactuca sativa. Applied Soil Ecology. 35, 480-487.

Merwin, H. D. and Peech, M. (1951). Exchange ability of soil potassium in the sand, silt and clay fractions as influenced by the nature and complementary exchangeable cations. Soil Science American Proceedings. 15, 125-128.
Nambiar, K. K. M. and Ghosh, A. B. (1984). All India Co-ordinated Research Project on long term fertilizer experiments and its research achievements. Fertilizer News. 30(4), 56-77.

Olsen, S. R. Cole, C. V. Watanable, F. S. and Dean, L. A. (1954). Estimation of available phosphorous in soil by extraction with sodium bicarbonate. USDA Circular. 939, 1-19.

Parmar, D. K. Verma, T.S. Deor, B.S. Mishra, A. and Vermani, A. (2006). Enhancing yield and profitability of a Western Himalayan vegetable production system by balancing nutrient inputs through farmyard manure and synthetic fertilizer applications. Journal of Sustainable Agriculture. 29, 89-99.

Peirce, L. C. (1987). Vegetable Characteristics, Production and Marketing. New York: John Willey and Sons.

Singh, A.K. and Singh, J. P. (1977). Effects of spacing and level of nitrogen at growth, yield and quality of garlic. Allahabd Farm. 58(4), 553-554.

Singh. A. K. (2004). Effect of nitrogen and phosphorus on growth and curd yield of cauliflower var. Snowball-16 under cold arid region of ladakh. Haryana Journal of Horticulture Science. 33 (1 \& 2), 127-129.

Subbiah, B.V. and Asija, G.L. (1956). Rapid procedure for the estimation of the available nitrogen in soils. Current Science. 25, 259-260.

Swain, D. K. Murmu, K. and Ghosh, B. C. (2013). Comparative assessment of conventional and organic nutrient management on crop growth and yield and soil fertility in tomato-sweet corn production system. Australian Journal of Crop Science. 7(11), 1617-1626.

Upadhyay, A. K. Bahadur, A. and Singh, J. (2012). Effect of organic manures and biofertilizers on yield, dry matter 
partitioning and quality traits of Walkley, A. and Black, T. A. (1934). An cabbage (Brassica oleracea var. estimation of soil organic matter and capitata). Indian Journal of proposed modification of the chromic Agricultural Sciences. 82(1), 31-34. acid titration method. Soil Science. 37, 29-38.

\section{How to cite this article:}

Meera Devi, Uday Sharma, Garima and Yourmila Kumari. 2018. Effect of Integrated Nutrient Management on Soil Physico-Chemical Properties and Yield of Capsicum (Capsicum annuum). Int.J.Curr.Microbiol.App.Sci. 7(05): 363-372. doi: https://doi.org/10.20546/ijcmas.2018.705.047 